\title{
Hiperpigmentação da Face Induzida por Tratamento com Olmesartan Medoxomilo-Hidroclorotiazida
}

\author{
Costa-Silva M', César A², Gomes NP³, Fernandes MS ${ }^{4}$, Azevedo F ${ }^{5}$ \\ 'Interno do Internato Complementar de Dermatologia e Venereologia/Resident, Dermatology and Venereology, Centro \\ Hospitalar São João, EPE, Porto, Portugal \\ 2Especialista de Dermatologia e Venereologia/ Consultant, Dermatology and Venereology, Centro Hospitalar São João, EPE, \\ Porto, Portugal \\ ${ }^{3}$ Interno do Internato Complementar de Dermatologia e Venereologia/Resident, Dermatology and Venereology, Centro \\ Hospitalar São João, EPE, Porto, Portugal \\ ${ }^{4}$ Interna do Internato Complementar de Anatomia Patológica/Resident, Anatomic Pathology, Centro Hospitalar São João, EPE, \\ Porto, Portugal \\ ${ }^{5}$ Diretora do Serviço de Dermatologia e Venereologia/Head of the Dermatology and Venereology Department, Centro Hospitalar \\ São João, EPE, Porto, Portugal
}

RESUMO - A hiperpigmentação cutânea com fotodistribuição pode ser despoletada por vários medicamentos. Descrevemos - caso de uma mulher de 69 anos que desenvolveu hiperpigmentação facial após tratamento com olmesartan medoxomilo-hidroclorotiazida e melhorou após a sua suspensão, sugerindo fortemente que a hiperpigmentação foi induzida pelo fármaco. O olmesartan medoxomilo-hidroclorotiazida deve ser adicionado à lista de medicamentos que podem induzir hiperpigmentação cutânea com fotodistribuição.

PALAVRAS-CHAVE - Distúrbios de Fotossensibilidade; Face; Hidroclorotiazida; Hiperpigmentação; Olmesartan Medoxomilo.

\section{Facial Hyperpigmentation Induced by Combination Therapy with Olmesartan Medoxomil- -Hydrochlorothiazide}

ABSTRACT - Photodistributed hyperpigmentation has been associated with several drugs. We describe a 69-year-old woman who developed facial skin hyperpigmentation starting after treatment with a combination of olmesartan medoxomil and hydrochlorothiazide and improving following its withdrawal, suggesting drug-induced dyspigmentation. Olmesartan medoxomil-hydrochlorothiazide should be added to the list of drugs that can induce photodistributed cutaneous hyperpigmentation.

KEYWORDS - Face; Hydrochlorothiazide; Hyperpigmentation; Photosensitivity Disorders; Olmesartan Medoxomil.

Correspondência: Miguel Ângelo da Costa e Silva Alameda Prof. Hernâni Monteiro

4200-319 Porto, Portugal

Tel.: 00351914113990

E-mail: miguelcostaesilva.dermato@gmail.com

DOI: https://dx.doi.org/10.29021/spdv.76.3.905
Recebido/Received

08 Fevereiro/February 2018

Aceite/Accepted

27 Março/March 2018 


\section{Caso Clínico}
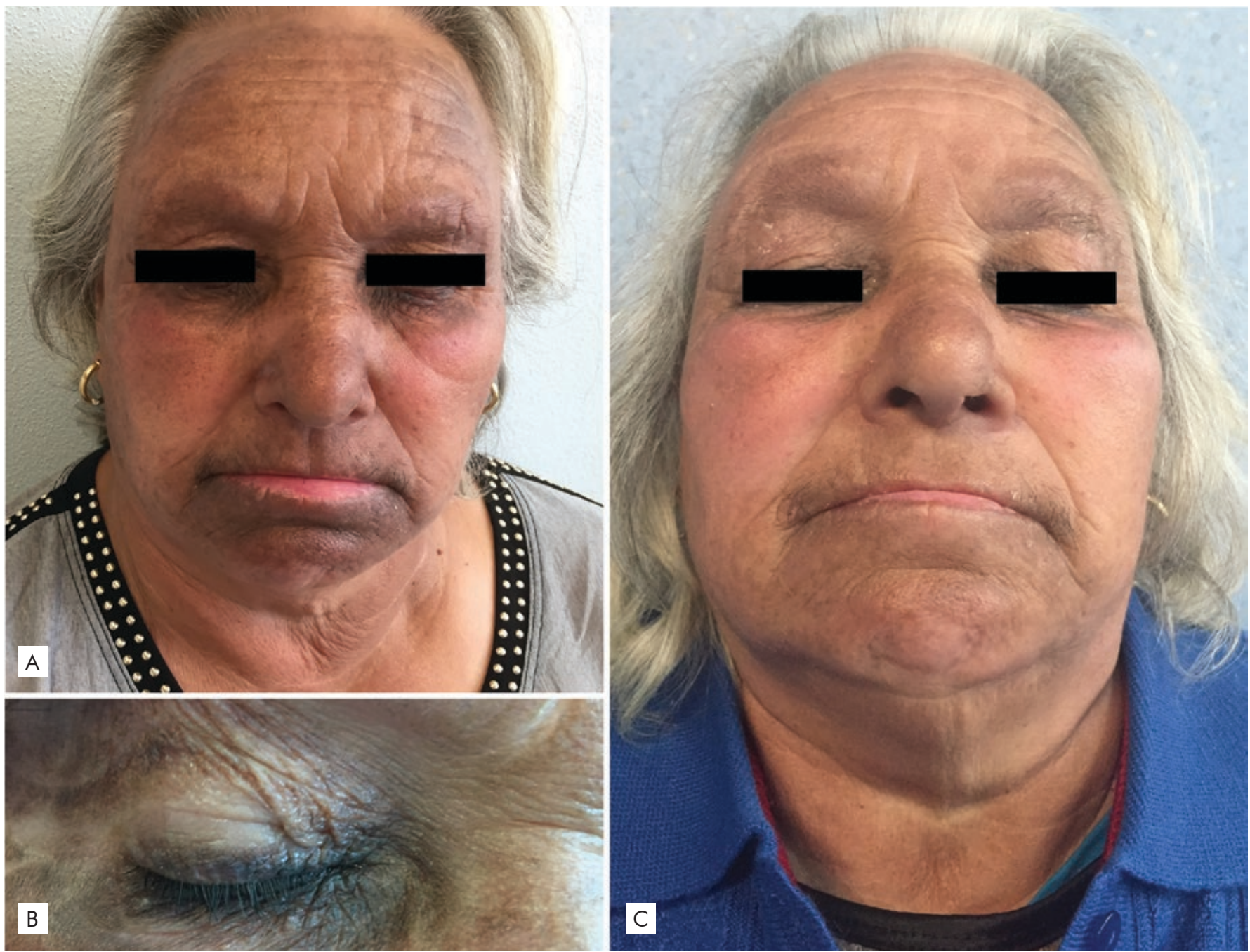

Figure 1 - Slate-gray hyperpigmentation on the face (A) sparing the cutaneous folds (B). Pigmentation fading 3 months after stopping olmesartan medoxomil-hydrochlorothiazide (C).

\section{INTRODUCTION}

APhotodistributed hyperpigmentation has been reported in association with several drugs. ${ }^{1}$ Olmesartan medoxomil-hydrochlorothiazide is a combination of an angiotensin II receptor antagonist and a thiazide diuretic used to treat arterial hypertension. We describe a patient who developed skin hyperpigmentation while being treated with a combination of olmesartan medoxomil-hydrochlorothiazide.

\section{CASE REPORT}

A 69-year-old woman was referred to our clinic with a two-month history of facial hyperpigmentation. Her medical history was unremarkable except for arterial hypertension diagnosed four months earlier treated with olmesartan medoxomil-hydrochlorothiazide $(40 \mathrm{~g} / 12.5$ mg) for three months. She denied associated symptoms such as burning sensation or pruritus, as well as previous erythema or scaling in the area. Physical examination showed a slate-gray hyperpigmentation on the face and sides of the neck sparing the cutaneous folds and mucous membranes (Fig. 1a-b). Laboratory investigations were unrevealing including the ACTH stimulation test. Histopathology revealed pigmentary incontinence with multiple melanophages dispersed in the dermis.

Photodistributed hyperpigmentation caused by antihypertensive treatment was suspected based on the clinical and histological features. Photoprotection along with replacement of olmesartan medoxomil-hydrochlorothiazide with amlodipine and nebivolol resulted in significant fading of the pigmentation at three months follow-up (Fig. 1c).

\section{DISCUSSION}

Drug-induced skin pigmentation is estimated to account for $10 \%$ to $20 \%$ of all cases of acquired 
hyperpigmentation. ${ }^{2}$ Drugs that have been reported to induce skin and/or mucous membrane discoloration include antimalarials, amiodarone, cytotoxic drugs, nonsteroidal anti-inflammatory drugs, tetracyclines, heavy metals, and psychotropic drugs. ${ }^{1-5}$ Antihypertensive drugs are one of the most commonly prescribed drugs, but reports of drug-related cutaneous hyperpigmentation are notably uncommon. In this respect, most cases are associated with diltiazem and amlodipine. ${ }^{3,6,7}$ Recently, Giménez-García, ${ }^{3}$ described for the first time dyspigmentation induced by combination therapy with telmisartan-hydrochlorothiazide. To the best of our knowledge, no case of cutaneous hyperpigmentation associated with olmesartan medoxomil-hydrochlorothiazide has been formally reported to date.

The pathogenesis of drug-induced dyspigmentation has not been fully elucidated. It relates to specific characteristics of the causative agent and can involve a dermal accumulation of melanin, of the culprit drug itself or drug complexes; synthesis of special pigments under the direct influence of the drug, such as lipofuscin; or dermal deposition of iron owing to drug-induced damage to dermal vessels. ${ }^{1,2}$ Clinical features are variable, with a large range of patterns, colors, and distributions. ${ }^{3}$ Lesions are often accentuated in sun-exposed areas as was the case in our patient. ${ }^{3}$

Treatment includes sun-avoidance measures and interruption of the offending drug, but Q-switched alexandrite laser therapy and topical immunomodulators have been successfully used in some cases. ${ }^{2,6,8}$ With these interventions, in most reported cases, improvement is slowly achieved. Nevertheless, hyperpigmentation may be permanent in some cases. ${ }^{1,2}$

Hyperpigmentation starting after olmesartan medoxomil-hydrochlorothiazide therapy and improving following its withdrawal strongly suggests that the dyspigmentation was drug-induced. Furthermore, both the clinical and histologic findings are similar with previous reports on this type of reaction with other antihypertensive drugs.

Olmesartan medoxomil-hydrochlorothiazide should be added to the list of drugs that can induce photodistributed cutaneous hyperpigmentation. Antihypertensive drugs, must be considered in the differential diagnosis of unexplained cutaneous hyperpigmentation with a clear photodistribution.

\section{Acknowledgment}

We thank to Dr. J Pardal and RP Silva for their contribution in this work, namely pathology investigation and examination.
Conflitos de interesse: Os autores declaram não possuir conflitos de interesse.

Suporte financeiro: $O$ presente trabalho não foi suportado por nenhum subsídio ou bolsa.

Confidencialidade dos dados: Os autores declaram ter seguido os protocolos do seu centro de trabalho acerca da publicação dos dados de doentes.

Protecção de pessoas e animais: Os autores declaram que os procedimentos seguidos estavam de acordo com os regulamentos estabelecidos pelos responsáveis da Comissão de Investigação Clínica e Ética e de acordo com a Declaração de Helsínquia da Associação Médica Mundial.

Consentimento dos doentes: Obtido.

Conflicts of interest: The authors have no conflicts of interest to declare.

Financing Support: This work has not received any contribution, grant or scholarship.

Confidentiality of data: The authors declare that they have followed the protocols of their work center on the publication of data from patients.

Protection of human and animal subjects: The authors declare that the procedures followed were in accordance with the regulations of the relevant clinical research ethics committee and with those of the Code of Ethics of the World Medical Association (Declaration of Helsinki).

Patients consent: Obtained.

\section{REFERENCES}

1. Garin Shkolnik T, Feuerman H, Didkovsky E, Kaplan I, Bergman R, Pavlovsky L, Hodak E. Blue-gray mucocutaneous discoloration: a new adverse effect of ezogabine. JAMA Dermatol. 2014; 150: 984-9.

2. Dereure O. Drug-induced skin pigmentation. Epidemiology, diagnosis and treatment. Am J Clin Dermatol. 2001; 2:253-62.

3. Giménez-García R. Hyperpigmentation induced by combination therapy with telmisartan-hydrochlorothiazide. J Clin Hypertens. 2016; 18: 361-2.

4. Granstein RD, Sober AJ. Drug-and heavy metal-induced hyperpigmentation. J Am Acad Dermatol. 1981; 5:1-18.

5. 5. Lerner EA, Sober AJ. Chemical and pharmacologic agents that cause hyperpigmentation or hypopigmentation of the skin. Dermatol Clin. 1988; 6:327-37.

6. Kubo Y, Fukumoto D, Ishigami T, Hida Y, Arase S. Diltiazem-associated photodistributed hyperpigmentation: report of two Japanese cases and published work review. J Dermatol. 2010; 37:807-11.

7. Erbagci Z. Amlodipine associated hyperpigmentation. Saudi Med J. 2004; 25:103-5.

8. Atkin DH, Fitzpatrick RE. Laser treatment of imipramine-induced hyperpigmentation. J Am Acad Dermatol. 2000; 43: $77-80$ 